\title{
Reaching Underserved Borrower Prospects: A Case Of A Small Rural Bank
}

Timothy C. Johnston, (Email: johnston@utm.edu), University of Tennessee at Martin

Alice Ann Yeargin, Greenfield Baking Company

Teresa Brundige, Banker

Tom Payne, University of Tennessee at Martin

\begin{abstract}
Banks want to serve all members of their market, to meet government regulations as well as to follow company policy. This paper describes a case study of the efforts of a small rural bank to develop a marketing plan to target potential borrowers in underserved groups. First, market demographic data were used to determine the current population size, income, and race composition of the market. Second, publicly available competitor data were used to assess peer banks in surrounding market areas. The third task was to identify underserved socio-economic groups and develop prospect lists. Fourth, the bank developed outreach efforts to promote bank financial services to target groups. Fifth, the bank delivered educational programs for target individuals and families. Sixth, the outreach efforts were evaluated. Finally, the bank considered options for promoting bank services to underserved residents in the future. This paper illustrates the difficulty for a small, rural bank to diversify its borrower base, and presents some efforts that a bank can take to pursue its goal of serving all members of its community.
\end{abstract}

\section{INTRODUCTION}

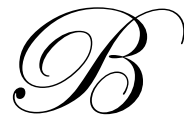

anks want to serve all members of their communities. One reason is to fulfill their charter as a community bank. Another reason is to follow corporate policies that direct managers to reach out to all members of society. The goal to serve the entire community sometimes leads banks to make special efforts to reach "underserved" people. Underserved can be defined as people who use financial services at a rate lower than their proportion in the market population. Underserved can also mean a group of people whose rate of borrowing, for example, is lower than the rate of other groups in the market. Underserved groups can be identified by income, gender, race, geography or other factors.

A study by the Association of Community Organizations for Reform Now (ACORN, 2003) found that (1) African-American applicants for conventional home purchase loans were two and one third times more likely to be turned down than white applicants, and (2) the disparity of denial rates cannot be explained by income, among other findings. ACORN concluded that "traditional lending institutions continue to fail to adequately serve low and moderate-income communities of all races."

This paper discusses a bank located in a rural Tennessee market, for which data is not as readily available as for urban markets. For example, for conventional home purchase loan applications in the Memphis metropolitan area the denial rate for African-Americans in 2003 was $24.8 \%$ as compared to the White denial rate of $11.3 \%$, for a disparity ratio of 2.2. The disparity ratio for Latinos was 1.8. Banks report these data under the Home Mortgage Development Act (HMDA) (ACORN, 2003).

The ACORN study made several recommendations, including one that "lenders should be more active in making good loans in minority and low-income communities." They suggest that lenders remove discrimination from their lending and outreach practices, and expand their partnerships with community-based organizations to make home purchase credit more available (p. 51). This paper describes a case study of the efforts of a small rural bank to develop a marketing plan to target potential borrowers in underserved groups. 


\section{LITERATURE REVIEW}

Small, rural banks have unique problems in managing their loan portfolios, when compared to large banks. According to Clark (1992), "small rural banks have limited access to sources of funding and limited opportunities to lend outside their immediate communities." Many large banks have branched within their home states and between states, but many small banks have stayed true to their geographic roots. According to Meyer \& Yeager (2001), "thousands of small banks with geographically concentrated offices remain and are likely to exist for some time. Some argue that small banks have a comparative advantage over large banks in small-business lending for which little public information about the borrower's creditworthiness is available. This advantage arises because small banks can originate and monitor relationship loans at a lower cost than larger banks."

The close relationships between a bank and its local market borrowers are an advantage and a disadvantage. It is an advantage because a bank with a deep knowledge of its market can make higher-quality loans. It can be a disadvantage because a bank can become focused on a narrowly defined, limited and possibly homogeneous market.

Small-towns banks that are part of a large corporation are faced with meeting both large-bank requirements and the needs of its customers in the community. This can be difficult, because the local market may not have the potential to yield the loan criteria mandated by the corporation to meet its regulatory guidelines. Also, rural lending practices may not dovetail with the parent bank's the reliance on quantitative criteria. According to Meyer \& Yeager (2001): "Management at small banks can more easily monitor loan offices; consequently small banks are better able to develop the community relationships necessary to underwrite small business loans." To contain costs, "larger banks often prefer to lend to customers for which credit information is more readily available. Consequently, community banks are likely to continue engaging in small-business lending where assessments of credit quality rely heavily on intangibles." In other words, a large parent bank's insistence on a quantitatively diverse borrower base may not consider the small bank lender's reliance on personal relationships and the makeup and condition of the local market.

The performance of rural banks may be tied with the condition of the local market. According to Meyer \& Yeager (2001) the association between local economic activity and bank performance "is more likely to be evident in the data for small banks with offices in rural areas than for other banks." They argue that this correlation is possible because "rural banks tend to lend to a relatively high percentage of firms and residents in their own counties" as compared to urban banks. Meyer \& Yeager analyzed the performance of small, independent rural banks in the Federal Reserve's Eighth District with county economic data in their respective markets. They concluded, "Geographical concentration is not a significant risk factor (and) that bank performance is not significantly correlated with county economic data," but cautioned that the lack of evidence of this relationship could be due to "noisy" (errorprone) county economic data.

In summary, the impact of local economic conditions on the performance of rural banks is a cause for concern and continued research. One expects the health of a bank to reflect the economic health of its market. By the same token, on expects a bank's borrower base to be a mirror of its market. A small rural bank may not have the opportunities to change its loan portfolio or borrower base that are available to a bank in a larger urban or multibranch environment. "A bank's location significantly influences its choice of borrowers because monitoring costs increase as the distance between lender and borrower increases. Hence, banks tend to make loans to the people and businesses that are geographically nearby" (Meyer \& Yeager, 2001).

This paper describes the efforts of a small, rural bank to increase lending to underserved markets. First, market demographic data and publicly available competitor data are used to assess the situation. Next, initial outreach efforts are discussed and evaluated. Finally, future outreach efforts are suggested. 


\section{RURAL BANK MARKETING PLAN}

What follows is a case study of the efforts of a small rural bank to develop a marketing plan to reach potential borrowers in underserved groups. The Rural Bank (a pseudonym) is an independently managed branch of the \$ multi-billion Regional Bank (also a pseudonym) with over 200 locations in several states.

Banks that operate in metropolitan areas, such as Regional Bank, must report their lending activities to HMDA. Branch banks, such as the Rural Bank branch of Regional Bank do not report directly to HMDA. The Rural Bank branch lending activity is reported internally and is compared independently with other local banks. Regional Bank has a corporate policy to make its financial products available to everyone in its markets. The Rural Bank branch performance is measured by a corporate policy to serve customers in proportion to their representation in the market, within a range. Regional Bank examines the diversity of its markets by geography, income, race, and other factors.

There were several goals that Rural Bank management wanted to obtain in this study. First, management wanted to determine the current population size and race composition for the bank's market area. Second, management was interested in loan data of peer group banks in surrounding market areas. Third, management wanted to identify underserved socio-economic groups in the bank's market area and to develop target group prospect lists. A fourth goal was to develop outreach efforts to promote bank financial services to the identified individuals or families. The fifth goal was to plan and deliver educational programs for identified individuals and families. The sixth and seventh goals were to evaluate the outreach efforts, and to develop future plans for delivering information about banking education, products, and services to underserved residents in the market. Table 1 summarizes the steps in the marketing plan.

\begin{tabular}{|l|l|}
\hline \multicolumn{2}{|c|}{ Table 1: Rural Bank Marketing Plan To Increase Diversity Among Borrowers } \\
\hline Goal 1 & Determine the current population size and race composition of the market. \\
\hline Goal 2 & Examine data on peer banks in surrounding market areas. \\
\hline Goal 3 & Identify underserved socio-economic groups and develop prospect lists. \\
\hline Goal 4 & Develop outreach efforts to promote bank financial services to target groups. \\
\hline Goal 5 & Deliver educational programs for target individuals and families. \\
\hline Goal 6 & Evaluate the outreach efforts. \\
\hline Goal 7 & Develop plans for promoting bank services to underserved residents. \\
\hline
\end{tabular}

\section{Goal 1}

The Weakley County Chamber of Commerce provided data from a recent U. S. census (2000) on the population size and race composition for the bank's market area. The five largest communities in the county were: Martin, Dresden, Greenfield Gleason, and Sharon. Table 2 summarizes these data.

\begin{tabular}{|l|c|c|c|c|}
\hline \multicolumn{5}{|c}{ Table 2: Weakley County Data On Population And Racial Composition } \\
\hline Area & Population & White & Black & Other \\
\hline Weakley County total & 34,895 & 31,501 & 2,424 & 970 \\
\hline City of Dresden & 2,855 & 2,699 & 124 & 32 \\
\hline City of Martin & 10,515 & 8,235 & 1,642 & 638 \\
\hline City of Gleason & 1,463 & 1,440 & 8 & 15 \\
\hline City of Greenfield & 2,208 & 1,998 & 189 & 21 \\
\hline City of Sharon & 988 & 881 & 101 & 6 \\
\hline Unincorporated areas & 16,866 & 16,248 & 360 & 258 \\
\hline
\end{tabular}


Whites make up $90 \%$ of the total population in Weakley County with blacks about $7 \%$ and others less than $3 \%$. The population of the 5 cities in the county ranges from less than 1,000 (Sharon) to more than 10,000 (Martin). The City of Martin is home to both the largest employer in the county, The University of Tennessee at Martin, and the second-largest employer, MTD Products.

Rural Bank also obtained U.S. Census data on Weakley County and the surrounding northwest Tennessee counties of Obion, Henry, and Carroll. The counties have roughly equal populations (from about 30,000 to over 34,000 people) and ethic compositions. Weakley County has the largest population $(34,895)$ and the highest proportion of White $(90.3 \%)$ and the lowest proportion of Black $(6.0 \%)$ residents. The "Other" race category makes up a relatively small proportion of the population, with Weakley County reporting the largest percentage at $2.7 \%$, which includes residents of Hispanic heritage. Table 3 summarizes these data.

\begin{tabular}{|l|c|c|c|c|c|c|c|}
\hline \multicolumn{7}{|c|}{ Table 3: Northwest Tennessee Counties Data On Population And Racial Composition } \\
\hline Area & Population & White & \% & Black & \% & Other & \% \\
\hline Weakley County & 34,895 & 31,501 & 90.3 & 2,424 & 6.9 & 970 & 2.7 \\
\hline Obion County & 32,450 & 28,607 & 88.2 & 3,196 & 9.8 & 647 & 1.9 \\
\hline Henry County & 31,115 & 27,757 & 89.2 & 2,787 & 9.0 & 571 & 1.8 \\
\hline Carroll County & 29,475 & 25,843 & 87.7 & 3,050 & 10.3 & 582 & 1.9 \\
\hline
\end{tabular}

Data from U. S. Census reports found at the Federal Financial Institutions Examination Council (FFIEC, 2005b) showed more detailed demographic information for the market area by census tract, including median family income, population, minority population and the number of owner-occupied housing units. These data show that the census tract that includes the western split of the City of Martin had the highest percentage of minority residents at over $19 \%$, and also had the largest median family income at $\$ 47,318$. The tract to the east included part of Martin and had the second largest minority percentage at over $14 \%$. These two tracts contain the City of Martin and The University of Tennessee at Martin. Table 4 summarizes these data.

The census tracts that contained the cities had minority populations that ranged from $3.3 \%$ in Gleason to $7.2 \%$ in Greenfield. The number of minority residents for the four cities ranged from only 152 to 315 people, and Weakley County was home to 3,577 minorities. In summary, these data show that the bank had a relatively small pool of potential minority borrowers from which to draw.

\begin{tabular}{|l|c|c|c|c|c|}
\hline \multicolumn{7}{|c|}{ Table 4: Summary Census Demographic Information For Weakley County } \\
\hline Census Tract Code & $\begin{array}{c}\text { 2003 Est. } \\
\text { Median Family } \\
\text { Income }\end{array}$ & $\begin{array}{c}\text { Tract } \\
\text { Population }\end{array}$ & $\begin{array}{c}\text { Tract } \\
\text { Minority \% }\end{array}$ & $\begin{array}{c}\text { Minority } \\
\text { Population }\end{array}$ & $\begin{array}{c}\text { Owner } \\
\text { Occupied } \\
\text { Units }\end{array}$ \\
\hline 9680.00 Chetsnut Glade & $\$ 38,220$ & 1344 & 1.93 & 26 & 468 \\
\hline 9681.00 E. Martin & $\$ 44,624$ & 4938 & 14.12 & 697 & 1420 \\
\hline 9682.00 W. Martin & $\$ 47,318$ & 9934 & 19.26 & 1913 & 1824 \\
\hline 9683.00 Sharon & $\$ 41,492$ & 2350 & 6.47 & 152 & 750 \\
\hline 9684.00 Dresden & $\$ 43,151$ & 6058 & 5.20 & 315 & 1701 \\
\hline 9685.00 Gleason & $\$ 34,109$ & 4819 & 3.30 & 159 & 1456 \\
\hline 9686.00 Greenfield & $\$ 39,573$ & 3929 & 7.20 & 283 & 1233 \\
\hline 9687.0 Palmersville & $\$ 35,366$ & 1523 & 2.10 & 32 & 510 \\
\hline
\end{tabular}

\section{Goal 2}

The second goal was to examine data on peer banks in or near the market area of interest. Data from two banks, referred to as Bank 1 and Bank 2, are presented here (the bank names are not disclosed to maintain privacy). Peer Bank 1 and Peer Bank 2 are similar banks, and competitors with locations in nearby towns. 
The bank obtained data on small business loans originated by the banks in Weakley County in 2003, by area income characteristics, loan amount at origination, and the number of loans to businesses with gross annual revenues of less than $\$ 1$ million. These data are from Community Reinvestment Act (CRA) disclosure statements found at the Federal Financial Institutions Examination Council (FFIEC, 2005a) web site. Tables 5 and 6 show these data.

\begin{tabular}{|l|c|c|c|c|}
\hline \multicolumn{4}{|c|}{ Table 5: Peer Bank 1 Small Business Loan Originations In Weakley County, TN (2003) } \\
\hline Market Area Income & $\begin{array}{c}\text { Loans } \\
<=\$ \mathbf{1 0 0 , 0 0 0}\end{array}$ & $\begin{array}{c}\text { Loans } \\
\mathbf{>} \mathbf{\$ 1 0 0 , 0 0 0}\end{array}$ & $\begin{array}{c}\text { Loans to Businesses } \\
\text { With <= } \mathbf{\$ 1} \text { million } \\
\text { Annual Revenues }\end{array}$ \\
\hline Low Income & 0 & 0 & 0 & 0 \\
\hline Mod. Income & 0 & 0 & 0 & 0 \\
\hline Mid. Income & 32 & 4 & 1 & 35 \\
\hline Upp. Income & 0 & 0 & 0 & 0 \\
\hline Income NA & 0 & 0 & 0 & 0 \\
\hline Total & 32 & 4 & 1 & 35 \\
\hline
\end{tabular}

\begin{tabular}{|l|c|c|c|c|}
\hline \multicolumn{4}{|c|}{ Table 6: Peer Bank 2 Small Business Loan Originations In Weakley County, TN (2003) } \\
\hline Market Area Income & $\begin{array}{c}\text { Loans } \\
<=\$ \mathbf{1 0 0 , 0 0 0}\end{array}$ & $\begin{array}{c}\text { Loans } \mathbf{> \$ 1 0 0 , 0 0 0} \\
<=\$ \mathbf{2 5 0 , 0 0 0}\end{array}$ & $\begin{array}{c}\text { Loans to Businesses } \\
\text { With < } \mathbf{\$ 1} \text { million } \\
\text { Annual Revenues }\end{array}$ \\
\hline Low Income & 0 & 0 & 0 & 0 \\
\hline Mod. Income & 0 & 0 & 0 & 0 \\
\hline Mid. Income & 40 & 2 & 6 & 41 \\
\hline Upp. Income & 0 & 0 & 0 & 0 \\
\hline Income NA & 0 & 0 & 0 & 0 \\
\hline Total & 40 & 2 & 6 & 41 \\
\hline
\end{tabular}

Peer Bank 1 originated all of its 37 loans in a middle-income market. A middle-income market has a Median Family Income is between $80 \%$ and $120 \%$ of the Market Area Median Family Income. The Market Area Median Family Income was $\$ 39,800$ in 2003. A large majority, 32 loans, was in the smallest loan amount category of less than $\$ 100,000$. The bank originated four mid-sized loans of between $\$ 100,000$ and $\$ 250,000$, and only one loan for greater than \$250,000. Most Peer Bank 1 loans were made to small businesses (35 of 37).

Peer Bank 2 originated 48 loans, all in a middle-income market area. A large majority, 40 loans, was also in the smallest loan amount category of less than $\$ 100,000$. The bank originated two mid-sized loans of between $\$ 100,000$ and $\$ 250,000$, and six loans for greater than $\$ 250,000$. Most loans by Peer Bank 2 were also made to small businesses (41 of 48).

These data show that the commercial loan business for the two banks consists of about 35-45 mostly small (less than $\$ 100,000$ ) loans made per year to mostly small businesses (less than $\$ 1$ million annual sales). The market is middle-income, defined by the Census as between $80 \%$ and $120 \%$ of the median family income. The race of the borrowers is not identified.

FFIEC (2205c) also provided data on the disposition of home loan applications, from bank reports as mandated by the Home Mortgage Disclosure Act, including mortgage loan application data for Weakley County in 2003 by type of loan (e.g. FHA, conventional, refinancing, etc.) and the outcome of the application (originated, denied, etc.). Tables 7 and 8 show loan application data for Peer Bank 1 and Peer Bank 2, respectively. 


\begin{tabular}{|l|c|c|c|c|c|c|}
\hline \multicolumn{7}{|c|}{ Table 7: Peer Bank 1 Home Mortgage Disclosure Act Data For Weakley County (2003) } \\
\hline & $\begin{array}{c}\text { FHA, FSA, } \\
\text { VA }\end{array}$ & Conventional & Refinancing & $\begin{array}{c}\text { Home } \\
\text { Improvement }\end{array}$ & $\begin{array}{c}\text { 5 or More } \\
\text { Families }\end{array}$ & $\begin{array}{c}\text { Nonoccupant } \\
\text { Loans }\end{array}$ \\
\hline Originated & 2 & 12 & 57 & 12 & 2 & 15 \\
\hline Not Accepted & 0 & 0 & 0 & 0 & 0 & 0 \\
\hline Denied & 0 & 1 & 7 & 1 & 0 & 0 \\
\hline Withdrawn & 0 & 2 & 4 & 1 & 0 & 1 \\
\hline Closed & 0 & 0 & 0 & 0 & 0 & 0 \\
\hline Total & 2 & 15 & 68 & 14 & 2 & 16 \\
\hline
\end{tabular}

\begin{tabular}{|l|c|c|c|c|c|c|}
\hline \multicolumn{7}{|c|}{ Table 8: Peer Bank 2 Home Mortgage Disclosure Act Data For Weakley County (2003) } \\
\hline & $\begin{array}{c}\text { FHA, FSA, } \\
\text { VA }\end{array}$ & Conventional & Refinancing & $\begin{array}{c}\text { Home } \\
\text { Improvement }\end{array}$ & $\begin{array}{c}\text { 5 or More } \\
\text { Families }\end{array}$ & $\begin{array}{c}\text { Nonoccupant } \\
\text { Loans }\end{array}$ \\
\hline Originated & 0 & 11 & 95 & 1 & 0 & 7 \\
\hline Not Accepted & 0 & 2 & 4 & 0 & 0 & 0 \\
\hline Denied & 0 & 0 & 4 & 0 & 0 & 0 \\
\hline Withdrawn & 0 & 2 & 4 & 0 & 0 & 0 \\
\hline Closed & 0 & 0 & 4 & 0 & 0 & 0 \\
\hline Total & 0 & 15 & 111 & 1 & 0 & 7 \\
\hline
\end{tabular}

These data show that Peer Bank 1 only originated 14 new home purchase mortgages in 2003, with the balance being loans for refinancing, home improvement, or rental properties. Peer Bank 2 only originated 11 new home loans. The race of the borrowers is not identified. A small loan volume does not provide much opportunity to change the makeup of the borrower base.

\section{Goal 3}

The third goal was to identify underserved socio-economic groups and develop prospect lists. This was accomplished by forming target group lists on which Rural Bank could focus its marketing efforts. Weakley County employers, including a manufacturing plant, a repackaging plant, and two nursing homes, reported wages for full time entry-level positions that ranged from $\$ 6.00$ to $\$ 8.25$ per hour. Table 9 contains these data.

\begin{tabular}{|l|c|}
\hline \multicolumn{2}{|c|}{ Table 9: Weakley County Wage Data } \\
\hline Company & Wage \\
\hline Repackaging (Southern Source) Plant & $\$ 6.00 / \mathrm{hr}$. \\
\hline Manufacturing (Parker Hannifin Corp.) Plant & $\$ 7.32 / \mathrm{hr}$. \\
\hline Nursing Home (VanAyer Manor) Nursing Assistants & $\$ 7.50 / \mathrm{hr} .-\$ 8.00 / \mathrm{hr}$. \\
\hline Nursing Home (Weakley County) Nursing Assistants & $\$ 7.75 / \mathrm{hr} .-\$ 8.25 / \mathrm{hr}$. \\
\hline
\end{tabular}

Rural Bank 's target group list would consist of individuals from our low to moderate-income group. These community members may not be aware of the financial products available to them.

\section{Goal 4}

The fourth goal was to develop outreach efforts to promote bank financial services to target groups. To complete this, a Housing Fair was developed to help families of Weakley County learn more about owning a home and the responsibilities it requires. This event showcased several products tailored to help those with less financial stability than others, such as people in the low-income peer group. These products included the Guaranteed Single Family Housing Loan Program from USDA Rural Development, and conventional fixed-rate and adjustable rate mortgages. 
Flyers were developed and distributed to a total of 875 employees of local businesses, nursing homes, and municipalities via individual paycheck stuffers. Posters were distributed to local business and libraries for display. Announcements appeared in four local newspapers for two weeks. The local radio station publicized the event on the air for two and a half weeks leading up to and on the day of the event, including coverage on a popular morning program that reached Weakley and adjacent counties. The event was promoted to Realtors, loan program specialists, local bankers, and appraisers to reach individuals currently looking for a home.

\section{Goal 5}

The fifth goal was to deliver educational programs for target individuals and families. The key event was the Housing Fair, which Rural Bank hosted at the activity center of a local church.

A USDA Rural Development Area Specialist presented the Guaranteed Single Family Housing Loan Program, which helps banks provide loans to individuals and families who might not otherwise qualify for conventional financing. She listed some benefits of the program from both the homeowner and lender's point of view. A bank employee introduced the Rural Bank 's services available through the Mortgage Department. A Rural Bank Loan Officer presented the basic loan services that are available at a community bank. A Marketing Intern presented basic housing cost information that new homeowners might want to consider before purchasing a home, such as city and county taxes, rural fire service, plumbing, winterizing, pest control and electricity costs. Two booklets provided by the Fannie Mae Foundation, "Opening the Door to a Home of Your Own" and "Choosing the Mortgage That's Right for You" were also provided. Additionally, budget worksheet materials were provided to help individuals determine their borrowing capabilities. Representatives from three realty offices were present to describe their services. Childcare was provided and refreshments were served.

\section{Goal 6}

The sixth goal was to evaluate the outreach efforts. The Housing Fair organizers were satisfied with the preparations for the event, and with the participation of the presenters. Yet despite the advertising, publicity, and personal contacts the attendance was disappointing. Why didn't more people in the target group attend the event? Possible explanations include: (1) People may have been uncomfortable attending an event sponsored by a bank or discussing a loan with a bank officer; (2) People may have had bad perception of their personal credit history; (3) People may have not had the job or income stability needed to buy a home; (4) People may not have seen the availability of affordable homes in their area; and (5) People may not have been in the market for a home at the time of the event.

\section{Goal 7}

The seventh goal was to develop additional plans for promoting bank services to underserved residents. An alternative to the Housing Fair would be visits to prospects' places of employment during working hours, rather than asking people to attend a special event during their time off. Rural Bank plans to offer a "financial literacy" training program to city employees, for example. This program teaches about financial institutions, the services they offer, and the benefits they provide to customers.

\section{CONCLUSION}

Banks want to serve all members of their market, to meet government regulations as well as to follow company policy. Small rural banks have some unique problems in meeting goals to broaden their customer base. First, they operate in markets with a small absolute number of potential customers. Reaching underserved customers, who also happen to be in the market for a home, and who are not current customers of another bank, is a challenging task. The Rural Bank case shows that a small bank can find data on its markets. Banks can conduct a good faith marketing effort relatively easily, one that can determine if there is an urgent need for financial products in its market. Beyond that, small banks may find that their business with underserved borrowers may have to be built like their business in general - one loan and one customer relationship at a time. 


\section{REFERENCES}

1. Association of Community Organizations for Reform Now (2003). The Great Divide: Home Purchase Mortgage Lending Nationally and in 115 Metropolitan Areas. October. Retrieved on February 18, 2005 from www.acorn.org/HMDA.

2. Clark, Michelle A. (1992). Are Small Rural Banks Credit-Constrained? A Look at the Seasonal Borrowing Privilege in the Eight Federal Reserve District. Federal Reserve Bank of St. Louis (May/June) 52-66.

3. Federal Financial Institutions Examination Council (2005a). 2003 CRA Institution Disclosure Statement, Federal Deposit Insurance Corporation, retrieved on February 18, 2005 from http://www.ffiec.gov/webcraad/ cradiscl.htm.

4. Federal Financial Institutions Examination Council (2005b). Census report - Summary Census Demographic Information for Tennessee: Weakley County, retrieved on February 18, 2005 from http://www.ffiec.gov/WebCensus/ffieccensus.htm.

5. Federal Financial Institutions Examination Council (2005c). Disposition of Loan Applications, by Location of Property and Type of Loan, 2003, Home Mortgage Disclosure Act Report, retrieved on February 18, 2005 from http://www.ffiec.gov/hmda rpt/dis_welcome.htm.

6. Meyer, Andrew P. \& Timothy J. Yeager (2001). Are Small Rural Banks Vulnerable to Local Economic Downturns? Federal Reserve Bank of St. Louis (March/April) 25-38.

\section{NOTES}

